\title{
KREDIBILITAS PEMUKA PENDAPAT DALAM TRADISI PERNIKAHAN DI BAWAH UMUR (PERNIKAHAN DINI) DI MADURA
}

\author{
Suyono \\ Program Studi Ilmu Komunikasi - Fakultas Ilmu Sosial dan Ilmu Politik \\ Universitas Muhammadiyah Jember \\ Jalan Karimata No. 49, Telp. 0331- 336728, Jember 68121 \\ Email: suyono.sulaiman@unmuhjember.ac.id
}

\begin{abstract}
Madurese tribes have been known to have unique cultures and customs. The traditions and customs of the Madurese people, so far well maintained, do not even fade even though modern culture aggressively engulfs young people. Including among them the "tradition" of underage marriage or often known early marriage. This early marriage tradition can be found in the Village of Sanatengah, Kec. Pasean, Kab. Pamekasan. Cases of early marriage in this village have remained until now. It cannot be separated from the influence of opinion leaders who are able to maintain the continuity of customs in the village. The purpose of this study was to examine in depth the relationship of the continuity of early marriage with the influence of opinion leaders who each opinion became the role model of the local community, so that the existing traditions maintained its existence. This research with qualitative descriptive method emphasizes the symbolic interactionalism approach, especially on the phenomenological dimension.
\end{abstract}

Keywords: Opinion Role, Early Marriage

\begin{abstract}
ABSTRAK
Masyarakat suku Madura selama ini dikenal memiliki kebudayaan dan adat-istiadat yang unik. Tradisi dan adat istiadat masyarakat Madura, sejauh ini terjaga dengan baik, bahkan tak luntur meski budaya modern gencar melanda kaum muda. Termasuk diantaranya "tradisi" pernikahan di bawah umur atau sering dikenal nikah dini. Tradisi nikah dini ini, dapat dijumpai di Desa Sanatengah, Kec. Pasean, Kab. Pamekasan. Kasus pernikahan dini di desa ini tetap bertahan hingga kini. Itu tidak terlepas dari pengaruh pemuka pendapat yang mampu mempertahankan keberlangsungan adat-istiadat di desa tersebut. Tujuan penelitian ini untuk mengkaji secara mendalam hubungan keberlangsungan pernikahan dini dengan pengaruh pemuka pendapat yang setiap pendapatnya menjadi panutan masyarakat setempat, sehingga tradisi yang ada tetap terjaga eksistenasinya. Penelitian dengan metode deskriptif kualitatif ini, menekankan pada pendekatan interaksionalisme simbolik, terutama pada dimensi fenomenologi.
\end{abstract}

Kata Kunci: Peran Pemuka Pendapat, Pernikahan Dini 


\section{PENDAHULUAN}

Era sudah jauh berubah, namun pernikahan dini, masih menjadi persoalan krusial di negeri ini. Pernikahan dini adalah praktek pernikahan yang melibatkan dua orang atau salah satu mempelainya masih di bawah umur. Di wilayah perkotaan, kasus nikah di bawah umur ini hampir bisa ditekan, karena berbagai sebab. Tingkat pendidikan yang relatif tinggi, baik orang tua maupun pelakunya. Namun berbeda dengan kawasan pedesaan, yang belum tersentuh modernitas. Kuatnya tradisi yang terus dipegangi masyarakat desa, khususnya desa-desa terpencil atau yang masuk wilayah pedalaman, kasus pernikahan dini masih banyak kita jumpai.

Sanatengah, merupakan salah satu desa, di wilayah Kecamatan Pasean, Pamekasan, Madura, yang lokasinya tergolong daerah terpencil, karena medannya yang sulit dijangkau. Wajar, kalau teknologi informasi dan komunikasi juga belum mampu "menyentuh" masyarakat secara penuh. Sehingga, masyarakat masih hidup dengan tradisi dan adat-istiadat yang dipegangi secara turuntemurun.

Yang menjadi persoalan, tidak semua adat-istiadat sesuai dengan kondisi zaman yang terus berkembang. Namun nilai-nilai tradisional tersebut, tetap tumbuh subur karena para tokoh pemuka pendapat masih memeganginya. Sementara warga masyarakat, akan tunduk dan patuh pada apa yang mereka kemukakan. Termasuk, tradisi menikahkan anak gadis mereka, meski usianya masih dibawah umur. Karenanya, gadis yang usianya masih 12 tahun, bukan hal yang tabu atau terlarang, untuk dinikahkan, kalau sudah ada jodohnya.

Desa yang berjarak sekitar $70 \mathrm{KM}$ dari kota kabupaten itu, warganya masih banyak yang melakukan praktik pernikahan dini dibawah umur (kurang dari 16 tahun). Seperti umumnya pernikahan, tentu seluruh persyaratan pernikahan terpenuhi, kecuali surat nikah yang sering tidak terlalu diperhatikan. Karena pernikahan di bawah umur ini, kerap dilakukan di bawah tangan atau yang dikenal masyarakat sebagai nikah sirri.

Dari segi ritual, tidak banyak beda dengan pernikahan pada umumnya. Namun, persoalan pada kasus pernikahan dini di Sanatengah ini, adalah kuatnya paham-paham tradisional warga setempat dalam memaknai sebuah proses pernikahan dan ditambah dengan dinamika sosial yang sudah berlangsung turuntemurun. Ditambah persoalan sikap patuh anak pada kedua orangtua dan juga kepada 
"petuah" kiai, semakin menguatkan tradisi pernikahan dini di tempat ini. Hal ini dapat dimaklumi, karena hamper sebagian besar anak-anak Madura, pernah mengenyam pendidikan di pondok-pondok pesantren, dan di pesantren itulah mereka menemukan jodoh atau dijodohkan. Dan tentunya, peran pemuka pendapat menjadi pilar penyangga keberlangsungan tradisi nikah di usia dini, hingga sekarang.

Keberadaan pondok pesantren yang cukup banyak di Madura dan sebagian menganut paham salafiyah, menjadi rujukan bagi masyarakat setempat untuk diikuti dan diteladani. Karena itu, peran pemuka pendapat seperti kiai, pangaseppo, pindere dan orang-orang berpengaruh lainnya, kerap dijadikan panutan oleh para orang tua untuk bekal kehidupan anak keturunannya. Termasuk kebiasaan menikahkan putra-putri mereka di usia dini, seolah mendapat "restu" para pemuka masyarakat. Tradisi nikah dini itupun tetap terjaga keberlangsungannya hingga kini.

Dalam penelitian ini, penulis mengasumsikan bahwa keberlanjutan (eksistensi) pernikahan di bawah umur (nikah dini) di desa ini, tidak terlepas dari pengaruh pemuka pendapat (opinien leader) terutama dalam opsi pembiaran bahkan pelestarian tradisi tersebut menjadi bagian tradisi yang sudah berlangsung lama dan menurun sampai generasi sekarang ini. Para pemuka pendapat yang ada di Desa Sanatengah meliputi: 1. Kiai, 2. Bendoro dan 3. Pangaseppo. Dari masing-masing pemuka pendapat tadi dalam eksistensi pernikahan dini memiliki peran masing-masing. Dan yang paling berperan dalam tradisi ini adalah Kiai (mak kaeh). Kiai dalam tradisi kedaerahan di Madura pada umumnya sangat disegani, bahkan popularitasnya mengalahkan camat bahkan bupati sekalipun. Oleh karena itu apa yang sudah menjadi keputusan kiai bagi masyarakat Madura tidak bedanya seperti ketentuan hukum yang harus dipatuhi. Dengan kata lain, pantang bagi orang Madura untuk menolak "titah" kiai.

Beda dengan "Kiai" untuk Bendoro adalah predikat yang diberikan kepada seseorang yang memiliki garis keturunan dari kiai atau alim "pemuka pendapat". Di lain sisi juga Bendoro menjadi sebutan bagi guru ngaji di kampung-kampung. Sedangkan Pangaseppo sama halnya dengan tokoh adat, adalah sosok pemuka pendapat yang yang berada di setiap Tanean Lanjeng (halaman panjang). Pangaseppo memiliki peran cukup signifikan terutama dalam tradisi bakalan (perjodohan) masyarakat madura. 
Penelitian ini menekankan pada komunikasi tradisi dalam pernikahan dini masyarakat Madura secara luas. Dapat dipahami bahwa studi ini mencoba untuk menjelaskan secara mendalam tentang komunikasi tradisi dalam membentuk interaksi yang terjadi antara komponenkomponen komunikasi yang mempunyai sub-sub tradisi, karakter tradisi dan membentuk komunikasi tradisi dalam pernikahan dini pada masyarakat Madura.

Peneliti menggunakan pendekatan teori interaksi simbolik. Mengingat, pendekatan teori ini cukup relevan dengan kondisi yang terjadi dan dialami masyarakat setempat, khususnya Desa Sanatengah. Disamping itu, peneliti juga masih memperkaya bahan kajian dengan teori lain, seperti teori Pragmatisme. Mulyana (2001:64).

Dalam pandangan Mulyana, realitas sejati itu tidaklah ada di dunia ini, kecuali kita sendiri yang mencoba menciptakan. Dijelaskannya, bahwa manusia akan mendasarkan pengetahuannya tentang dunia, lebih kepada apa yang terbukti dan juga berguna bagi kehidupan mereka. Selanjutnya, definisi obyek secara fisik dan sosia, lebih didasarkan pada apa yang ditemui dan sesuai dengan kegunaan serta tujuan hidup manusia. Dan kita akan mampu memahami orang lain, kalau kita paham dengan apa yang sedang dilakukan di dunia ini.

Sebagaimana halnya dengan kehidupan manusia, sebagai individu selalu menekankan interaksi dengan individu atau kelompok lain. Misalnya seorang dosen berinteraksi dengan mahasiswanya dan bahkan interaksi tradisi dalam komunikasi tradisi pernikahan dini dini juga berinteraksi dengan elemenelemen yang lain di lingkungannya.

Untuk mempelajari interaksi sosial tersebut yang merupakan bagian terpenting dari komunikasi dibutuhkan pendekatan yaitu "Interaksionisme Simbolik", dari kata interaksionisme ini sudah jelas bahwa sasarannya pada interaksi sosial, sedang kata simbolis mengacu pada penggunaan simboliksimbolik dalam melakukan interaksi.

Kriteria pemuka pendapat, tentu berbeda antara satu daerah dengan daerah lainnya. Namun secara umum, seorang pemuka pendapat adalah orang yang ditokohkan di satu tempat, karena memiliki kelebihan yang tidak dipunyai anggota masyarakat pada umumnya. Kelebihan itu, antara lain dapat ditunjukkan dengan gelar kebangsawanan, kemampuan menyesuai diri dengan lingkungannya, dan punya pengetahuan yang cukup tentang adat-istiadat yang 
dipegang-teguhi sebagaian besar warga masyarakat.

Seperti pendapat Homanas (1961), yang menyatakan: "Seseorang yang memiliki status sosial tinggi (pemimpin pendapat) akan senantiasa memelihara nilai-nilai serta norma kelompoknya sebagai syarat minimal dalam mempertahankan statusnya." (Depari dan Andrew, 1982).

Istilah opinion leader (pemuka pendapat), banyak dibahas dalam literatur ilmu komunikasi sekitar tahun1950-1960. Sebelumnya, pembahasan terkait dengan hal ini, masih seputar istilah influential, tastemakers atau influencers untuk menyebut pemuka pendapat (opinion leader). Istilah ini banyak dipakai di kalangan masyarakat pedesaan, mengingat masyarakat desa rata-rata tingkat pendidikannya masih rendah, sehingga peran pemuka pendapat sangat besar, terutama untuk menyelesaikan persoalanpersoalan yang mungkin timbul.

Pernikahan adalah bersatunya dua anak manusia yang diikat dengan tali perkawinan. Sementara pernikahan dini merupakan ikatan perkawinan yang salah satu mempelai atau dua-duanya, masih di bawah umur, menurut ketentuan undangundang.
Sedangkan, Yusuf Qordhawi (2003:267), menjelaskan bahwa pernikahan merupakan suatu proses percampuran, penyatuan, stabilisasi, transaksi dan perjanjian yang kuat dan kokoh. Pernikahan dibangun atas niat pergaulan yang abadi dari para pihak (kedua mempelai), untuk merealisasikan buah psikologis yang meliputi kedamaian, ketentraman batin, cinta kasih sayang untuk tujuan kemakmuran bumi dan melestarikan keturunan.

Dalam UU RI No.1/1974 pasal1 yang berbunyi : "Perkawinan adalah ikatan lahir batin antara seorang pria dengan seorang wanita sebagai suami istri dengan tujuan untuk membentuk keluarga (rumah tangga) yang bahagia dan kekal berdasarkan Ketuhanan Yang Maha Esa”.

Sedangkan definisi pernikahan dini dalam "Kompilasi Hukum Islam" (KHI) tertulis: "Pernikahan dini yaitu suatu akad yang sangat kuat atau mitsqan ghlizhan untuk mentaati perintah Allah dan melaksanakannya merupakan ibadah".

Lain lagi dengan definisi pernikahan dini dalam pandangan masyarakat secara umum dengan melihat skala tradisi dan adat istiadat yang ada di masyarakat, banyak melahirkan berbagai persepsi (pandangan), yang berbeda-beda. Perbedaan tersebut lahir karena dilatar 
belakangi asumsi tradisi, kepercayaan, keturunan dan persepsi golongan yang terus tumbuh secara turun-temurun dan antar generasi. Begitu juga yang terjadi di Sanatengah, Madura, pandangan masyarakat akan makna pernikahan dini tidak sama dengan yang terjadi dalam masyarakat secara umum yaitu siklus adat membentuk karakter tersendiri yang mereka yakini dan mereka percaya sebagai suatu perilaku kebenaran dan menjunjung tinggi sosial diantara mereka.

\section{METODE}

Penelitian dengan deskriptifkualitatif ini, metode pendekatannya lebih kearah interaksionalisme simbolik dan berdimensi fenomenologi. Metode kualitatif akan menghasilkan data deskriptif yang mendeskripsikan kata dan kalimat, baik lisan maupun tertulis, dari pihak-pihak yang diamati. Sementara, deskriptif dipakai untuk menggambarkan fakta atau karakteristik populasi tertentu, secara sistematis, faktual dan cermat (Isaac dan Mickhael dalam Rakhmat, 1991: 22).

Penelitiaan ini dimaksudkan untuk mengetahui sesuatu yang menjadi kebiasaan sebagai suatu kesatuan yang utuh dan tidak terikat dengan hipotesa tertentu melalui pengamatan secara langsung. Penelitian, melakukan interaksi langsung dengan subjek penelitian atau pihak-pihak yang diteliti, sehingga memudahkan untuk menemukan persoalan-persoalan serta bersikap peka dan mudah untuk menyesuaikan diri pada setiap pengaruh yang terdapat dalam obyek penelitian.

Metode penelitian kualitatif dengan pola fenomenologi menggunakan pendekatan yang holistic, sehingga dalam melihat objek bukan hanya parsial tapi natural. Sedang Muhadjir (1992: 28-29), berpendapat bahwa pendekatan fenomenologi menuntut bersatunya subjek peneliti dengan subjek pendukung dari suatu objek penelitian.

Mengingat komunikasi merupakan sebuah proses, dan proses itu terdiri dari serangkaian tindakan dari peristiwa yang berlangsung beberapa saat untuk menuju suatu hasil tertentu. Komunikasi hakikatnya merupakan proses penyampaian pesan komunikator kepada komunikan. Karena itu, proses komunikasi melibatkan empat aspek yang meliputi komunikator, pesan, saluran dan komunikan. (Emery dkk, $1970: 7$ ).

$$
\text { Koentjaraningrat }
$$
memberikan gambaran tentang informan yang meliputi informan pangkal dan informan kunci. Untuk informan pangkal dapat didefinisikan sebagai orang yang 
dinilai mampu memberikan informasi, baik secara umum serta mampu menunjukkan pihak lain sebagai informan kunci, untuk menyampaikan informasi lebih lanjut. Terkait dengan pemilihan informan ini, peneliti memilih sampel secara purposive (Nasution, 1992 : 32).

Adapun hal-hal yang akan menjadi fokus penelitian, meliputi: para pemuka pendapat yang ada Desa Sanatengah yang sudah ditentukan peneliti, pihak-pihak yang layak memberi keterangan terkait proses pernikahan di bawah umur (nikah dini), sejumlah mak kaeh (kiai) sebagai figur utama, beberapa bendoro yang punya banyak peran di masyarakat setempat, sejumlah pangasepoh dan pihak lain yang memiliki peran sentral dalam terkait adatistiadat masyarakat. Disamping tentunya, sejumlah pelaku nikah dini.

Dalam penelitian ini diperlukan data primer dan sekunder. Data primer penulis peroleh dari pengumpulan berbagai informasi dari informan di lapangan, yang dilakukan dengan pengamatan dan wawancara. Data sekunder dipakai sebagai data pendukung. Data sekunder ini, berupa dokumen, berbagai publikasi, dan data lainnya terkait dengan tradisi nikah dini di Madura yang sedang diteliti. Adapun teknik yang digunakan, selain observasi parsipatif, juga dengan wawancara tidak terstruktur, serta studi kepustakaan / dokumentasi.

Teknik keabsahan data, menggunakan teori (Patton, $1987: 331$ ) dan (Moleong, 1991 : 178), yakni dengan teknik perpanjangan-keikutsertaan, teknik triangulasi dan teknik diskusi teman sejawat. Untuk perpanjangankeikutsertaan dilakukan dengan menambah lamanya masa penelitian. Sementara, teknik triangulasi yang dilakukan, yakni triangulasi sumber dan triangulasi teori.

\section{PEMBAHASAN}

\section{Peran Pemuka Pendapat}

Kabupaten Pamekasan, merupakan salah satu wilayah kabupaten di kepulauan Madura. Untuk Desa Sanatengah, yang berada di wilayah Kec. Pasean, termasuk desa terpencil yang jaraknya hamper 55 $\mathrm{km}$ dari pusat kota. Masyarakatnya hidup dari hasil pertanian, dengan taraf kehidupan rata-rata menengah ke bawah.

Sebenarnya, tipologi masyarakatnya sudah tergolong maju, karena kehidupan masyarakatnya memang tidak jauh berbeda dengan masyarakat desa lainnya. Namun, uniknya masyarakat setempat masih memegang teguh adat-istiadat yang bersumber dari ajaran Islam kultural. Hal ini dimungkinkan akibat pengaruh kuatnya 
pengaruh pendidikan pondok pesantren yang tumbuh dan berkembang di desa tersebut. "Budaya santri" inilah yang kemudian menegasikan kuatnya peran tokoh ulama dan tokoh masyarakat, sebagai bentuk kepatuhan mereka. Sehingga norma-norma hidup bagi masyarakat desa ini, didominasi oleh tindakan atau ucapan yang diperlihatkan oleh para tokoh pemuka pendapat.

Untuk menuju Desa Sanatengah baik dari pusat kecamatan maupun dari kota kabupaten hanya mempunyai satu jalur utama transportasi, yang membentang dari utara ke selatan tepatnya membelah di tengah-tengah desa dengan kondisi jalan yang sudah diaspal walaupun disana-sini banyak yang berlubang dan sangat membahayakan bagi pengendara. Dan salah satu transportasi yang biasa menempuh jalur tersebut adalah pick-up (mobil pengangkut barang) yang juga dimanfaatkan masyarakat sebagai jasa angkutan terutama ke pasar tradisional setempat.

Masyarakat Sanatengah selama ini mengandalkan hidupnya kegiatan pertanian, baik sebagai pemilik lahan maupun sekadar menjadi buruh tani dengan tanaman pokoknya adalah tembakau, jagung dan padi dan sedikit sekali yang berprofesi sebagai pedagang.
Dalam memenuhi kebutuhan setiap hari di desa tersebut hanya tersedia satu pasar yaitu pasar Teleng yang operasinya hanya pada Rabu saja.

Desa Sanatengah luasnya berkisar 1.366,103 Ha, dengan peta demografi sebagai berikut : tanah tegal: $1.030,102$ Ha, tanah peternakan: $54 \mathrm{Ha}$, tanah pekarangan: $227 \mathrm{Ha}$, dan tanah kuburan: 15 Ha. Adapun batas-batas wilayah Desa Sanatengah, Kecamatan Pasean, Kabupaten Pamekasan untuk bagian utara berbatasan dengan Desa Dempobarat, bagian selatan berbatasan dengan Desa Sanah Laok,. Sedangkan di bagian barat, berbatasan dengan Desa Sanahdaja, dan timur dengan Desa Leppeng Barat.

Jumlah penduduk yang menghuni desa ini berkisar 8.772 jiwa, (laki-laki sebanyak: 2.873 jiwa dan perempuan: 5.899 jiwa). Mereka terdiri dari sekitar 3.472 KK (kepala keluarga), dengan kehidupan masyarakatnya yang agamis tradisionalis, yaitu masyarakat yang fanatik terhadap agama namun unsurunsur tardisonal masih melekat dalam kesehariannya.

Pemuka pendapat atau yang biasa kita kenal dengan tokoh adat, tidak terkecuali di Sanatengah, ada beberapa tingkatan yang merupakan pengakuan akan fungsi dan tugas yang berbeda-beda. 
Mereka biasanya dikenal dengan sebutan Mak Kaeh (Kiai atau Ulama Pengasuh/pemilik Pesantren), Pangaseppo (orang yang dituakan/dihormati), dan Bendoro/Lora (biasanya anak Kiai atau anak Pengasuh Pesantren).

Mak Kaeh adalah sebutan bagi para kiai atau pengasuh pesantren. Mereka akan menjadi panutan masyarakat dalam berbagai hal menyangkut kehidupan sehari-hari. Meski demikian, Mak Kaeh melakukan keputusan adat setelah mendapat permintaan dari Pangaseppo, Bendoro (Lora) maupun langsung permintaan orang tua mempelai. Mak Kaeh juga merangkap sebagai penghulu atau juru nikah, kapasitas dirinya tidak ubahnya sepeti modin yang setiap saat selalu siap sedia ketika dibutuhkan dalam proses penikahan, termasuk kasus pernikahan dini

Tokoh pemuka pendapat lainnya yang berpengaruh adalah Bendoro. Kalau di Jawa dikenal sebagai lora. Tokoh ini tidak lain adalh seseorang yang lahir di lingkungan pesantren dan punya nasab pada kiai, terutama kiai dengan trah tinggi atau kiai "berdarah biru.” Namun ada juga julukan bendoro yang dinisbatkan pada orang yang mendarmabaktikan hidupnya dengan mengajar ngaji atau guru ngaji di masjid, mushallah, dan tempat lainnya.
Di Sanatengah, Bendoro juga menampung permasalahan-permasalahan sosial kemasyarakatan dan membantu mencarikan penyelesaiannya. Terutama masalah-masalah yang tidak bisa diatasi oleh Pangaseppo, misalnya dalam melakukan pinangan atau melamar seseorang biasanya Bendoro yang melakukan setelah sebelumnya Pangaseppo yang meminta dan Pangaseppo sendiri sebagai orang yang membuka pintu komunikasi awal antara pihak keluarga kedua mempelai (Sudahri : 2013)

Pangaseppo berasal dari kata Panga artinya keagungan, kehormatan sedangkan Seppo artinya seppuh, tua. Titel atau pangkat Pangaseppo diberikan kepada seorang laki-laki atau perempuan biasanya sepuh namun memiliki kharisma dibanding yang lainnya, mempunyai hubungan sosial yang baik, manajemen lobinya handal, dipercaya oleh masyarakat, cakap dan responsif terhadap dinamika lingkungan (sudahri : 2013)

Pangaseppo adalah seorang yang tidak dipilih, tidak pula di tunjuk namun secara alamiah dia di percaya masyarakat untuk mengambil kebijakan-kebijakan tertentu dalam menangani permasalahn sosial termasuk didalamnya dalam hal pernikahan dini dini. Sehingga dalam hal 
pernikahan dini Pangaseppo adalah orang yang pertama yang harus di ajak bicara, kemudian dialah juga yang membuka komunikasi interpersonal atau persuasi dengan pihak-pihak yang berkepentingan dengan pernikahan dini tersebut.

Bajingan adalah pemuka pendapat yang disandangkan pada preman desa. Bajingan yang berasal dari kata dasar bajing, identik terhadap hewan yang selalu mencuri, mengambil sesuatu yang bukan haknya, hal itu disandangkan kepada kebiasaan orang yang mempunyai kebiasaan buruk seperti mengambil hak orang lain, suka berbuat keonaran, dan lain-lain, profil orang seperti itu akhirnya di panggil dengan sebutan bajingan.

Predikat jelek tak patut untuk di tiru dan tak pantas untuk dijadikan panutan, namun yang terjadi di Desa Sanatengah bajingan oleh sebagian masyarakat dijadikan sebagi tokoh atau pemuka pendapat, dengan alasan mereka memiliki tempat khusus di masyarakat. Seorang bajingan, rata-rata memiliki keberanian lebih, dan dalam kasus pernikahan dini, peran bajingan ini dibutuhkan untuk menjadi mediasi mulai dari pra pernikahan, saat proses pernikahan maupun ketika pasca pernikahan dini. Sekali lagi proses ini tanpa melalui pemilihan dan penunjukan sebelumnya.
Alasan lainnya, pernikahan dini tidak selamanya berjalan sesuai rencana. Persaingan calon mempelai laki-laki untuk mempersunting seorang gadis, kerap diwarnai ancaman dan bahkan perkelahian (carok). Seorang bajingan yang sudah punya nama besar, tentu akan memuluskan proses negoisasi, apabila ada pihak-pihak yang mencoba menghalangi rencana pernikahan tersebut. Keterlibatan para tokoh masyarakat dalam "kasus" nikah di usia muda di desa ini (Sanatengah), sangatlah signifikan dalam menentukan dan memutuskan persoalan pernikahan dini. Karena hampir semua tahapan pernikahan dini selalu melibat tokoh pemuka pendapat.

\section{Rangkaian Proses Pernikahan Masyarakat Madura}

Rangkaian pernikahan di masyarakat Madura biasanya diawali dengan kegiatan pranikah yang meliputi: tojukkabatton, yang merupakan awal dari komunikasi kedua pihak atau perkenalan antar keluarga. Keluarga mempelai pria biasanya diwakilkan kepada para pemuka pendapat (Pangaseppo atau Bendoro), mendatangi kediaman keluarga mempelai wanita yang akan dijadikan istri. Ini dilakukan untuk memastikan bahwa calon 
istri yang akan disunting, belum terikat dengan pria lain.

Jika dalam pertemuan tersebut disepakati bahwa si perempuan masih sendiri, maka Pemuka pendapat menyampaikan salam awal dari keluarga laki-laki sebagai komunikasi pembuka pintu, dalam siklus ini pihak perempuan belum sama sekali diikat atau di pinang. Pada kesempatan inilah, pihak calon pengantin pria kembali datang untuk acara Pasang Sabin (memasang tanda ikatan), yang diwakili keluarga inti dari ayah dan ibu pihak mempelai pria, serta tak lupa didampingi tokoh pemuka pendapat tersebut.

Bentuk pasang sabin disini, pihak laki-laki menyampaikan maksud kehadirannya kepada pihak perempuan, dalam hal keinginan untuk meminang si perempuan. Apabila dari pihak perempuan ada kata-kata persetujuan, maka pihak laki-laki memberikan semacam pengikat ala kadarnya kepada perempuan. Biasanya dalam hal ini berbentuk cincin, uang maupun pakaian kepada si perempuan. Dan inilah yang disebut dengan istilah Pasang sabin. Kalau perempuan ada pasang sabinnya maka dia sudah dianggap ada yang punya atau ada yang memiliki.

Tahap berikutnya, pihak laki-laki melakukan proses lamaran (meminang calon perempuan). Pada tradisi lamaran pihak yang datang adalah pemuka pendapat (Pangaseppo atau Bendoro) dan rombongan dari mempelai pria dan keluarga besarnya, menyerahkan berbagai buah tangan berupa kue dan buah-buahan yang jumlahnya sudah ditetapkan dan disetujui oleh dua keluarga (pihak perempuan). Kegiatan ini dikenal dengan istilah so'onan. So'onan harus ganjil minimal berjumlah 7 so'onan (satuan bungkusan) dan maksimal 21 so'onan dan yang membawa so'onan paling depan biasanya membawa kambing atau ayam jago sesuai kemampuan pihak laki-laki, kemudian disusul paningset (mahar) berupa pakaian lengkap kemudian jajanan dan buah-buahan. So'onan diberikan secara seremonial dari wali mempelai putera kepada wali mempelai puteri.

Langkah selanjutnya, pihak keluarga wanita melakukan upacara balasan mabalin (artinya mengembalikan). Upacara ini menandakan bahwa mempelai wanita menerima pinangan calon mempelai pria, dan sekaligus menunjukkan keseriusan pihak wanita untuk melanjutkan ke proses berikutnya, atau ke jenjang perkawinan.

Pihak perempuan melakukan mabalin, di dalamnya juga membawa so'onan (bingkisan atau oleh-oleh) 
biasanya tidak jauh berbeda dengan yang di bawa pihak laki-laki pada saat tradisi lamaran, namun ada istilah Monjul, yaitu so'onan dari pihak perempuan kecenderungan jumlahnya lebih banyak dari so'onan ketika lamaran pihak laki-laki sebelumnya.

Setelah melewati proses lamaran, maka tradisi selanjutnya adalah pingitan. Tradisi ini hanya dikhususkan untuk mempelai wanita. Pingitan ini dilakukan dengan menitipkan si calon istri, di rumah 9biasanya di lingkungan pondok pesantren) tempat seorang pemuka pendapat yang ditunjuk, selama hamper tujuh hari, sebelum acara pernikahan dilaksanakan.

Terkait dengan tradisi memingit (pingitan) ini, si calon mempelai wanita biasanya setiap harinya di fungsikan sebagai kerabat abdi dalem pesantren, yaitu melakukan aktivitas setiap hari sebagaimana hadam (pembantu kiai) atau seperti yang dikerjakan santriwati lainnya. Misalnya seperti memasak di dalem kiai, menyapu, ngarit (mencari rumput) untuk manaknan sapi dan aktivitas-aktivitas yang lainnya. Selama dipingit calon mempelai puteri banyak mendapatkan ilmu terutama ilmu agama, khususnya ilmu yang berkaitan dengan rumah tangga Islami.
Tahap selanjutnya adalah lamaran nikah yang dilaksanakan sehari menjelang proses penikahan. Sama seperti tradisi sebelumnya, calon mempelai pria akan membawa perlengkapan pernikahan (so'onan) yang jumlahnya jauh lebih besar dan lebih lengkap, karena meliputi kebutuhan peralatan rumah tangga, berupa meja-kursi, almari, tempat tidur dan lainlainnya, disamping juga ada maskawin dan peralatan kecantikan wanita lainnya.

Lamaran nikah berupa alat-alat dapur, kursi, ranjang, lemari dan lain-lain, pada dasarnya bukan menjadi pemberian suka rela pihak laki-laki kepada pihak perempuan, apabila nantinya terjadi perceraian, seluruh barang bawaan, aksesoris akan di bawa pulang kembali oleh pihak laki-laki sampai tidak tersisa. Karena pernikahan ini dilakukan di bawah tangan ataunya tidak dicatatkan pada KUA, atau dalam bahasa masyarakat setempat disebut kawin gantung, maka apabila terjadi perceraian, harta gono-gini menjadi hak milik suami. Dan baru dilakukan pembagian apabila dalam pernikahan itu mereka mempunyai keturan sebagai ahli waris.

Masyarakat Madura merupakan masyarakat transisi dari masyarakat tradisional kultural menuju masyarakat modern, termasuk juga masyarakat yang 
ada di Desa Sanatengah. Kekuatan adat masih mendominasi dalam memutuskan perkara tertentu, termasuk di dalamnya dalam urusan pernikahan. Pemuka pendapat sebagai tokoh sekaligus pemuka pendapat menjadi salah satu yang mendapatkan peranan penting dalam mempertahankan dan melestarikan adatistiadat masyarakat yang sudah ada sejak lama dan turun-temurun.

Tradisi pernikahan dini yang pada kebanyakan masyarakat modern sudah mulai di anggap tabu dan bahkan menyalahi undang-undang pernikahan yang ada. Di desa Sanatengah masih terjadi praktek pernikahan dini dengan usia mempelai masih di bawah umur (di bawah usia 16 tahun) dan dalam pernikahan dini tersebut juga masih ada yang dilakukan di bawah tangan (tidak tercatat di kantor urusan agama).

Pengaruh pondok pesantren yang sudah melingkupi kehidupan masyarakat setempat, menjadikan adat-istiadat yang melibatkan tokoh masyarakat dan pemuka pendapat di desa ini terus terjaga eksistensi hingga sekarang. Pesantren bukan lagi menjadi tempat menimba ilmu agama bagi masyarakat, tapi lebih dari itu, budaya yang tercipta dari intensitas hubungan masyarakat dengan pengampu pesantren, seolah menjadi norma yang baik untuk diikuti dan dilestarikan. Termasuk diantaranya, tradisi perjodohan antara santri laki-laki dan perempuan, yang kerap dimediaasi (mak comblang) pihak pengasuh pesantren.

Namun sangat disayangkan, tradisi yang sudah baik, yakni menjodohkan anak-anak mereka dengan memperhatikan bibit, bobot, dan bebet yang jelas, tidak diimbangi dengan norma social pada umumnya, seperti menikahkan anak mereka dalam usia yang cukup dewasa dan proses pernikahannya dilaksanakan oleh pejabat pencatat nikah seperti petugas KUA. Sehingga pernikahan anak-anak mereka menjadi sah menurut agama dan pemerintah, karena tercatat secara resmi, bukan nikah di bawah tangan atau nikah sirri.

Upaya penyadaran bukannya tidak dilakukan. Banyak pihak, terutama pihak berwenang yang terkait sudah kerap melakukan sosialisasi. Namun seperti diakui oleh sejumlah tokoh masyarkat, untuk mengubah tradisi ternyata tidak semudah membalik tangan. "Memang mengubah tradisi tidak mudah, tokoh ulama dan tokoh masyarakat sudah terlanjut meyakini apa yang selama ini sudah mereka lakukan," ujarnya.

Dalam masyarakat Madura, khususnya di Desa Sanatengah, 
pernikahan dini dilaksanakan dengan berbagai macam cara: pertama, dilakukan dengan cara sembunyi-sembunyi dalam artian pernikahan dini dilaksanakan dengan hanya dihadiri oleh keluarga dan kerabat dengan kedua mempelai, kedua; pernikahan dini dilaksanakan dengan acara yang meriah seperti pelaksanaan pernikahan dini masyarakat kebanyakan bahkan acaranya lebih meriah karena ada serangkaian acara penyerta yang tidak cukup dilaksanakan dalam waktu sehari melainkan sampai beberapa hari lamanya.

Sesuai perkembangan yang ada budaya pernikahan dini sudah mengalami penurunan dari tahun ketahun karena masyarakat sudah banyak belajar dari pengalaman selama ini bahwa efek dari pernikahan dini cenderung banyak mudhoratnya dari pada manfaatnya terutama dalam hal ini kerugian bagi pihak perempuan, yang tidak bisa melakukan akses dalam menuntut keadilan secara hukum ketika ada permasalahan seperti perceraian. Tapi lain halnya dengan pernikahan dini atau di bawah umur, praktek pernikahan dini ini masih sulit untuk dikendalikan disamping karena faktor tradisi yang sudah menjadi bagian dari masyarakat serta masalah rendahnya pendidikan juga menjadi penyebabnya.
Disisi lain tradisi ini tetap berlangsung bukan tanpa alasan. Pemuka pendapat Madura masih menganut paham islam tradisonalis fundamentalis, dalam artian agama dipahami dengan mengedepankan contoh Rasulullah dalam mempraktekkan suatu perkara termasuk dalam urusan pernikahan dini. Rasulullah Muhammad menikahi istrinya Aisyah yang usianya masih belia kurang lebih 7 tahun. Aturan perundang-undangan yang mengatur tata cara pernikahan dini hanya dipadang sebagai bagian dari usaha ikhtiar pemerintah untuk mengendalikan, memonitor dan mengatur persoalan pernikahan dini, secara kanon asasi islam tidak menjadi unsur syarat sahnya sebuah pernikahan dini, hal itu lebih pada kepentingan administratif pemerintahan.

Berdasarkan pengamatan peneliti, fenomena pernikahan dini dini sampai sekarang masih terus terjadi karena beberapa faktor: pertama, karena rendahnya pendidikan sehingga pondok pesantren masih menjadi alternatif favorit orang tua dalam mencari wadah pendidikan terhadap anak. Kedua, Peran pemuka pendapat (tokoh adat) termasuk Pemuka pendapat yang masih mempertahankan tradisi kuno di tengahtengah arus modernisasi yang terus berkembang. Ketiga, Tingkat kemiskinan 
yang belum banyak tersentuh oleh kebijakan pemerintah dengan program pemberdayaan masyarakat terutama dalam hal pengentasan kemiskinan dan buta aksara. Keempat, akses media komunikasi dan informasi belum secara merata menyentuh unsur basis masyarakat golongan bawah (grass root).

Untuk prosesi akad nikah dalam pernikahan dini di desa ini, sebenarnya tidak bedanya dengan pernikahan pada umumnya. Hanya yang sedikit beda adalah, mempelai wanita harus disembunyikan dahulu sampai prosesi akan nikah selesai dilaksanakan. Baru setelah selesai ijab-kobul, mereka boleh dipertemukan atau disebut temu manten. Dan proses akad nikah biasanya dilakukan oleh pemuka pendapat Mak Kaeh (sebutan terhadap seorang Pemuka pendapat) sebagai wakil wali perempuan, setelah sebelumnya ada proses serah terima perwalian. Kemudian setelah itu Mak Kaeh melakukan proses akad nikah.

Manten pria dan wanita kemudian saling bersalaman, selanjutnya mendapat nasihat atau tauziah dari Mak kaeh maupun dari Bendoro, yang isinya tidak jauh dari urusan menata kesiapan dan persiapan mempelai dalam menapaki hidup baru dalam biduk rumah tangga dengan impian kebahagiaan dunia akhirat, dan mencapai keluarga harmonis, Sakinah, mawaddah dan warohmah.

Setelah prosesi akad nikah dalam adat masyarakat Sanatengah, biasanya dilanjutkan dengan acara sungkeman. Diawali dengan sungkem kepada kedua orang tua masing-masing. Kemudian, dilanjutkan kepada sanak keluarga lainnya. Setelah itu, mempelai pria harus mencari keluarga inti mempelai wanita untuk sungkem. Begitu sebaliknya.

Prosesi selanjutnya adalah jemangan, yakni kedua mempelai disandingkan di atas pelaminan. Pengantin pria biasanya cukup memakai pakaian taqwa (busana muslim) atau memakai jas hitam. Sebaliknya, pengantin wanita cukup memakai gaun busana muslimah, tidak mengenakan pakaian pengantin seperti pada umumnya.

Kecuali bagi keluarga yang mampu secara ekonomi, jemangan dilakukan dengan mewah mengikuti prosesi adatistiadat Madura yang cukup fantastis dan meriah dengan serangkaian tradisi yang cukup panjang dan tidak jauh berbeda dengan tradisi Pernikahan dini dini di Jawa.

Setelah acara jemangan, tradisi terakhir adalah tradisi nyabis, pada fase ini kedua mempelai di ajak keliling untuk beramah tamah, bersalam-salaman dengan 
undangan yang hadir, sanak keluarga, famili dan tetangga yang hadir dalam acara tersebut. Yang unik, selesai prosesi jemangan, kedua temanten ini diarak keliling ketempat undangan yang hadir dan dilanjutkan masuk rumah dan mengelilingi seluruh bagian rumah termasuk dapur.

Tidak berhenti di situ, usai pernikahan pun kedua mempelai masih harus menjali prosesi pingitan. Dalam hal ini kedua mempelai merumahkan diri dan tidak diperkenankan keluar rumah selama kurang lebih 4 hari dari acara pernikahan dini. Tradisi tersebut bertujuan agar kedua mempelai melakukan proses adaptasi, perkenalan lebih mendalam antara satu dengan yang lainnya agar tercipta keserasian, kesesuaian dan persamaan persepi diri masing-masing pihak.

Berikutnya, pihak laki-laki biasanya melakukan upacara ngunduh mantu. Hal ini dilakukan sebagai upaya memanjatkan rasa syukur kepada Tuhan YME. Pelaksanaan manten lake' waktunya biasanya tidak terlalu jauh dari prosesi pernikahan dini sebelumnya (dikeluarga perempuan), dalam acara tersebut sudah tidak ada lagi kegiatan-kegiatan adat, mempelai pun duduk berbaur dengan undangan yang ada. Kalaupun ada penambahan acara biasanya diisi dengan kegiatan yang sifatnya hiburan rakyat.
Tradisi Ngalencer (main manten). Tradisi ini sebagai kelanjutan dari prosesi akan nikah, yakni dengan mengenalkan kedua mempelai kepada keluarga besarnya masing-masing. Biasanya dalam kegiatan ngalencer tadi pihak perempuan banyak menerima pemberian-pemberian yang disebut dengan Ontalan dari sanak saudara, pemberian tersebut bisa berupa uang, pakaian bahkan berupa ternak seperti ayam.

Yang tidak kalah pentingnya, mempelai juga harus melakukan tradisi yang biasa disebut nyabis. Nyabis artinya mengunjungi tokoh masyarakat, terutama ulama pengasuh pesantren yang berpengaruh, untuk mendapat doa restu (syafa'at guruh). Mereka berkunjung dengan membawa sesuatu, baik berupa uang maupun barang lainnya, dengan didampingi keluarga masing-masing.

Tradisi nyabis biasanya dilakukan setelah tradisi ngalencer dimana keluarga laki-laki dan keluarga perempuan ikut ngereng (ikut mendampingi) manten ke dalem (rumah) kiai. Tradisi ini pada dasarnya tidak termasuk pada siklus dari rangkaian acara wajib pernikahan dini, melainkan sebagai acara pelengkap karena acara nyabis tidak diatur dan terikat oleh ruang dan waktu. Bagi masyarakat Madura tradisi nyabis adalah bagian dari kegiatan 
pengabdian pada Pemuka pendapat (terutama terhadap guru ngaji) yang biasa dilakukan ketika ada keperluan tertentu atau sekedar kebutuhan petuah (berguru) tentang ilmu agama.

Untuk kasus pernikahan dini di desa (Sanatengah) ini, tidak banyak menggunakan simbol-simbol tradisi sebagaimana yang terjadi pada pernikahan dini-pernikahan dini di pulau Jawa. Seperti penggunaan Penjor yang biasa diapakai oleh orang Jawa sebagai penanda pernikahan dini yang biasanya ditaruk dipintu masuk lokasi pernikahan dini. Tradisi nginjak telur juga jarang dilakukan sebagai bagian dari rangkaian pernikahan dini. Meski demikian symbol yang banyak dipakai oleh masyarakat, biasanya berupa tulisan-tulisan kaligrafi yang indah, yang pasang di sudut rumah mempelai. Ini menandakan bahwa masyarakat Madura adalah masyarakat agamis dan mayoritas dari kalangan santri.

Sama halnya dengan bentuk pernikahan dini yang lain, dalam pernikahan dini dini dan pernikahan dini di bawah tangan masyarakat Madura masih mempertahankan tradisi-tradisi yang bersifat konvensional seperti tradisi membawa perkakas atau alat-alat rumah tangga yang dalam hal ini menjadi kekhususan untuk manten pria ke rumah manten wanita dimana hal ini sebagai simbol pemersatuan dan keseriusan seorang laki-laki dalam menikahi seorang wanita. Akan tetapi seperti sudah dijelaskan di atas, apabila terjadi perceraian maka perkakas atau alat-alat rumah tangga tersebut akan di bawa pulang kembali.

\section{Dampak kasus pernikahan dini}

Proses pernikahan dini yang melibatkan dua calon mempelai yang masih di bawah umur, tentu berdampak besar bagi masyarakat setempat. Salah satunya, menurut data yang ada kasus perceraian di desa ini ternyata cukup besar. Hal ini, karena perkawinan yang mereka lakukan masih melibatkan para pihak yang belum matang kejiwaannya. Sehingga perselisihan yang terjadi pasca pernikahan kerap terjadi dan ujung-ujungnya pada proses perceraian.

Dampak lainnya, pihak istri yang terpaksa bercerai, kerap lebih menderita dibanding mempelai pria. Sang pria bias dengan cepat menikah kembali, sementara sang istri, lebih banyak memilih mengurunmg diri dari pergaulan sosial, karena biasanmya mereka dan keluarga besarnya, merasa malu dan tercemat nama baiknya, apabila pernikahannya kandas di tengah jalan. 
Ada beberapa kejadian dalam proses penyesuaian hidup berumah tangga kedua mempelai lebih lama dari pasangan sebagaimana pasangan manten di daerah lain. Seperti di ceritakan pada hasil penelitian peneliti sebelumnya bahwa pernikahan dini dini terjadi antar tetangga atau sasoma dan masih saudara dekat (sataretanan). Pernikahan dini terjadi dimana kedua mempelai adalah teman sepermainan sejak kecil dimana komunikasi interpersonal yang terbangun selama ini adalah komunikasi persaudaraan, penuh keakraban dan jauh dari unsur-unsur biologis. Dan mereka tidak memahami bahwa proses perjodohan yang dibangun sepihak oleh orang tua sudah sejak lama, bahkan mereka masih balita atau belum cukup umur. Sebagian pernikahan dini yang terkesan dipaksakan tersebut tidak membuahkan hasil sebagimana yang diharapkan oleh kedua belah pihak.

Budaya perceraian menjadi pemandangan yang biasa di desa ini. Perceraian yang mereka lakukan tentunya menyimpan banyak masalah, diantarnya masalah sosial. Mempelai wanita yang mengalami perceraian, sering menjadi korban. Mereka sudah tidak punya harga diri dan kepercayaan dirinya runtuh. Mengingat, saat mereka melakukan pernikahan dini, masa depannya seolah terenggut. Kesempatan belajar di bangku sekolah dan kesempatan meraih masa depan, seolah telah terenggut.

Wajar kalau sampai saat ini, banyak diantara mereka yang bercerai dan tidak menikah kembali, memilih meninggalkan kampung halamannya mengadu nasib menjadi buruh migran di luar negeri, khususnya ke Arab Saudi dan juga Malaysia. Mereka mencoba bertahan hidup, dengan menjadi TKW, dan rela meninggalkan anak-anak hasil pernikahan yang dilakukan secara dini. Sedangkan sang suami biasanya justru menikah lagi dengan perempuan lain. Tentu yang menjadi korban adalah anak-anak mereka. Biasanya, anak hasil pernikahan dini ini dititipkan pada kakek-nenek dan saudara lainnya, karena ditinggal oleh orang tuanya.

\section{SIMPULAN}

Berdasarkan penjelasan dan pemaparan data tersebut simpulan dari penelitian ini, pertama tradisi masyarakat Desa Sanatengah, cukup beragam, namun yang menonjol adalah tradisi nikah dini atau nikah di bawah umur. Tradisi nikah di usia dini ini ternyata tetap terpelihara, tak lekang oleh arus modernitas yang terjadi di belahan dunia lainnya. Disamping 
tentunya berbagai tradisi masyarakat lainnya, yang patut untuk dilestarikan dan dibudayakan. Seperti tarian, kerajinan, dan adat-istiadat lainnya

Kedua, dari hasil penelitian ditemukan eksistensi tradisi pernikahan dini ini, terus bertahan karena pengaruh yang kuat dari kalangan pemuka pendapat, terutama pengaruh pondok pesantren yang terus mempertahankan tradisi. Munculnya hegemonisasi kebijakan para pemuka pendapat, pengkultusan terhadap pemuka pendapat, menjadi penyebab tradisi ini terus berlanjut turun-temurun.

Dampak dari pernikahan dini ini, kasus perceraian yang terjadi di Desa Sanatengah, Kecamatan Pasean, Pamekasan ternayata jumlahnya cukup besar. Mengingat, sebagian besar pernikahan dini dilakukan di bawah tangan, artinya pernikahan mereka hanya dilakukan oleh seorang pemuka agama dan tanpa dicatatkan ke Kantor Urusan Agama (KAU). Sehingga, mereka tidak punya legalitas sebagai pasangan suami istri. Sehingga, kasus kawin cerai menjadi budaya yang terelakkan.

\section{DAFTAR PUSTAKA}

Arifin, Anwar, H., (1988), Ilmu Komunikasi, Sebuah Pengantar Ringkas, Jakarta, PT. Rajagrafindo Persada.

Effendy, Onong Uchjana. (2000). Ilmu Komunikasi; Teori dan Praktek. Rosyada Karya : Bandung.

Garna, Judistira K. (1996). Ilmu-ilmu Sosial : Dasar-Konsep-Posisi. Program

Pasca Sarjana Universitas Padjajaran : Bandung.

Koentjaraningrat. (1990). Pengantar Ilmu Antropologi. Rineka Cipta : Jakarta. Liliweri, Alo. (2001). Komunikasi Verbal dan Nonverbal. PT.Citra Adtya Bhakti : Bandung. 
Moleong, Lexy.J. (1991). Metodologi

Penelitian Kualitatif. Remaja

Rosyada Karya : Bandung.

Muhadjir, Noeng. (1992). Metodologi

Penelitian Kualitatif. Rake Sarasin :

Yogyakarta.

Mulyana, Deddy. (2000). Ilmu

Komunikasi; Suatu Pengantar.

Remaja Rosyada Karya : Bandung.

Nasution, S.(1992). Metode Penelitian

Naturalistik Kualitatif. Taristo :

Bandung.

Qardhawi, Yusuf. (2003). Halal Haram;

Dalam Islam. Inter Media :

Surakarta.

Rahmat, Jalaludin. (2000). Psikologi Komunikasi. Rosyada Karya :

Bandung. 